\title{
Workshop Kurikulum 2013 Di Madrasah Ibtidaiyah Daarusshofa Karang Tengah-Kota Tangerang
}

\author{
Dr. Lili Nurlaili, M.Ed ${ }^{1}$

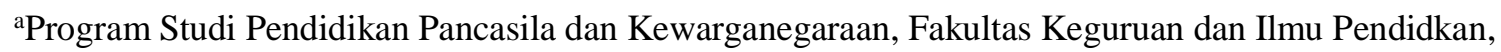 \\ Universitas Pamulang, Tangerang Selatan* \\ ${ }^{1}$ lilinurlaili@unpam.ac.id \\ *korespondensi penulis
}

Naskah diterima: 10 September 2021, direvisi: 15 September, disetujui: 26 September 2021

\begin{abstract}
Abstrak
Kurikulum 2013 yang telah dilaksanakan di seluruh Indonesia masih banyak kendala dalam implementasinya di sekolah, termasuk di Madrasah Ibtidaiyah Daarushofa Karang TengahKota Tangerang. Sekolah ini telah melaksanakan kurikulum 2013 semenjak tahun 2016, akan tetapi masih merasakan beberapa kendala dalam implementasinya. Tujuan pengabdian masyarakat di sekolah tersebut adalah memberikan pemahaman, pendalaman dan praktek membuat perangkat pembelajaran. Metode yang digunakan dalam workshop kurikulum 2013 yaitu ceramah bervariasi, tanya jawab, tayangan video pembelajaran, praktek menyusun silabus dan RPP serta praktek mengajar. Hasil pelaksanaan kegiatan yaitu seperangkat model pembelajaran, silabus, RPP dan penilaian. Kegiatan ini sangat bermanfaat, terutama bagi sekolah yang masih belum sempurna melaksanakan kurikulum 2013. Perlu dilakukan pendampingan menyeluruh pada sekolah tersebut dalam melaksanakan kurikulum 2013.
\end{abstract}

Kata-kata kunci: Kurikulum 2013; Pembelajaran; Penilaian

\begin{tabular}{l} 
Abstract \\
\hline The 2013 curriculum that has been implemented in Indonesia, until now still has many \\
obstacles in its implementation in schools, including at Madrasah Ibtidaiyah Daarushofa \\
Karang Tengah-Tangerang City. This school has implemented the 2013 curriculum since \\
2016, but still feels some obstacles in its implementation. The purpose of community service at \\
the school is to provide understanding, deepening and practice of making learning tools. The \\
methods used in the workshop are varied lectures, questions and answers, learning video \\
shows, practice in compiling syllabus and lesson plans and teaching practice. The results of \\
the implementation of the activity are a set of learning models, syllabus, lesson plans and \\
assessments. This activity is very useful, especially for schools that are still not perfect in \\
implementing the 2013 curriculum. It is necessary to provide comprehensive assistance to \\
these schools in implementing the 2013 curriculum
\end{tabular}

Keywords: Curriculum 2013; Learning; Assessment 


\section{PENDAHULUAN}

Pengertian kurikulum yang tercantum dalam Undang-Undang Sistem Pendidikan Nasional pasal 1 butir 19 yaitu : "kurikulum adalah seperangkat rencana dan pengaturan mengenai tujuan, isi, dan bahan pelajaran serta cara yang digunakan sebagai pedoman dalam penyelenggaraan kegiatan pembelajaran untuk mencapai tujuan Pendidikan tertentu”. Jadi dapatlah dikatakan bahwa kurikulum adalah serangkaian bahasan atau materi pengajaran yang dipersiapkan oleh guru atau tenaga pendidikan, sehingga arah kegiatan menjadi jelas.

Kurikulum yang berlaku di Indonesia semenjak tahun 2013 adalah kurikulum 2013. Pengembangan kurikulum 2013 dilakukan dengan mempertimbangkan beberapa aspek yaitu: (1) tuntutan Kompetensi Abad 21 yaitu peserta didik membutuhkan kualitas karakter dalam menghadapi lingkungan yang selalu berubah, maka peserta didik membutuhkan: iman dan taqwa; cinta tanah air, rasa ingin tahu, inisiatif, gigih, kemampuan beradaptasi, kepemimpinan yang jujur, kesadaran social dan budaya. Selain itu, kompetensi abad 21 yang juga harus dimiliki peserta didik yaitu kompetensi/kemampuan menghadapi tantangan kehidupan yang komplek, berpikir kritis/memecahkan masalah, kreativitas, komunikasi, dan kolaborasi. Tuntutan kompetensi abad 21 lainnya adalah kemampuan peserta didik terhadap Literasi dasar, bagaimana menerapkan keterampilan inti untuk kegiatan sehari-hari antara lain: literasi Bahasa dan sastra, literasi numerasi, literasi sains, literasi digital, literasi keuangan, literasi budaya dan kewarganegaraan. (2) pencapaian kompetensi berpikir tingkat tinggi yaitu peserta didik tidak hanya mampu "mengingat, memahami dan menerapkan", akan tetapi peserta didik harus mampu "menganalisis, mengevaluasi dan mengkreasikan". (3) penciptaan kesempatan kerja. Dengan Kurikulum 2013 diharapkan generasi muda di Indonesia tidak hanya berpikir untuk mencari pekerjaan, akan tetapi mereka akan mampu menciptakan pekerjaan di lingkungan mereka masing-masing, sehingga ekonomi Indonesia akan menjadi kuat dan peserta didik siap menghadapi generasi emas Indonesia di tahun 2045. (4) Kurikulum 2013 juga memperhatikan tingkat perkembangan peserta didik yang dibagi menjadi tiga tahap yaitu pra konvensional (6-10 tahun); konvensional (10-17) dan pasca konvensional (17-28 tahun).

Sampai tahun 2021, pelaksanaan kurikulum 2013 masih menghadapi berbagai kendala di lapangan, misalnya sekolah belum mengetahui perangkat/dokumen yang perlu mereka persiapkan (Dokumen 1 sampai 4), 
silabus, Rencana Pelaksanaan Pembelajaran (RPP), penilaian, pembelajaran yang inovatif, remedial pengayaan dan lainnya.

Demikian juga Madrasah Ibtidaiyah Daarushofa Karang Tengah - Kota Tangerang tempat kegiatan Pengabdian Kepada Masyarakat (PKM) Universitas Pamulang yang masih belum memahami pelaksanaan kurikulum 2013 yang baik dan benar. Terutama dalam aspek kelengkapan dokumen kurikulum 2013, pembelajaran dan penilaiannya. Berdasarkan hal tersebut, Tim (PKM) Unpam merasa terpanggil dan melakukan "Workshop Kurikulum 2013" di sekolah tersebut selama tiga hari yaitu tanggal 5-7 Juli 2021 dan bekerjasama dengan Penerbit PT. Yudhistira.

Di dalam kegiatan sosialisasi kurikulum 2013 oleh Pusat Pengembangan Kurikulum dan Perbukuan (Puskurbuk) Balitbang Kemdikbud tahun 2014 dijelaskan bahwa Sekolah yang akan melaksanakan kurikulum 2013 dapat meningkatkan kapasitas Pendidik dan Tenaga Kependidikan (PTK) dengan cara antara lain: (1) Mempelajari seluruh dokumen terkait Kurikulum 2013 melalui belajar mandiri, forumforum pendidik dan tenaga kependidikan, sehingga sekolah yang belum paham dengan kurikulum 2013 dapat belajar pada sekolah yang sudah paham ataupun menjadi sekolah "pilot proyek" kurikulum 2013 yang langsung mendapat bimbingan dari Puskurbuk; (2)
Melakukan Workshop, pelatihan, seminar terkait Kurikulum 2013. Sekolah yang belum memahami kurikulum 2013 dapat melakukan workshop, pelatihan dan seminar dengan melibatkan sekolah yang telah memahami kurikulum 2013; (3) Melakukan kolaborasi dengan sekolah rujukan, sekolah Pembina yang telah memahami kurikulum 2013, sehingga mereka akan dapat materi dan pembekalan yang lengkap dari sekolah rujukan tersebut; (4) melaksanakan Kurikulum 2013 dengan kemampuan yang dimiliki dan banyak bertanya pada dinas Pendidikan, pengawas di lingkungannya; (5) Bersifat pro-aktif mencari informasi terkait Kurikulum 2013 dari berbagai sumber, baik dari nara sumber, buku-buku, pedoman-pedoman, dan sekolah rujukan yang ada di setiap propinsi di Indonesia.

Kegiatan Pengabdian Kepada Masyarakat (PKM) yang dilaksanakan dalam bentuk "workshop kurikulum 2013" pernah dilakukan di daerah lain, yaitu: (1) Jurusan Pendidikan Guru Madrasah Ibtidaiyah IAIN Surabaya pada tahun 2018, peserta adalah guruguru Madrasah Ibtidaiyah Se-Kecamatan Kartasura.. Mereka membagi workshop dalam tiga sesi yaitu sesi pertama diisi dengan pembahasan materi orietnasi Kurikulum 2013. Sesi kedua diisi dengan pembahasan materi bedah Rencana Pelaksanaan Pembelajaran Kurikulum 2013 dan Sesi ketiga diisi dengan kegiatan pembahasan penilaian sesuai kurikulum 
2013. (2) Workshop penilaian kurikulum 2013 yang dilaksanakan oleh FKIP UNRAM tahun 2019 di Yayasan Al Azhar NW. Kayangan pada tahun 2019. (3) Workshop implementasi kurikulum 2013 bagi guru SD/MI di Kabupaten Kampar yang dilaksanakan oleh mahasiswa Universitas Terbuka dan Universitas Sultan Syarif Kasim Riau tahun 2019. (4) Workshop pembelajaran tematik terpadu berbasis inovatif dan kreatif bagi guru-guru di kota Belitar yang dilaksanakan oleh mahasiswa Fakultas Ilmu Pendidikan Universitas Negri Malang pada tahun 2017. (5) Seminar dan workshop pembelajaran berbasis kurikulum 2013 bagi guru-guru SD di Kecamatan Busungbiu, Kabupaten Buleleng-Propinsi Bali pada tahun 2017 yang dilaksanakan oleh mahasiswa FIP Undiksa.

Penelitian yang terkait dengan Kegiatan Pengabdian Masyarakat yang pernah dilakukan, antara lain: (1) Inovasi Pendidikan dalam Efektivitas Penerapan Kurikulum 2013 oleh Redmon windu gumanti tahun 2020 dan sudah di publish di Jurnal Syntax Imperatif; (2) Effektifitas Kurikulum 2013 dalam Proses Pembelajaran Pendidikan Agama Islam dan Budi Pekerti di kelas XI SMA Negeri Bona oleh Cici Alfiana tahun 2019 yang merupakan judul skripsi S1 beliau di Program Studi Pendidikan Agama Islam Fakultas Agama Islam Universitas Muhammadiyah Makassar; (3) Efektivitas Penerapan Kurikulum 2013 dalam
Meningkatkan Mutu Pembelajaran PAI dan Budi Pekerti di SMPN 2 Wonomulyo Provinsi Sulawesi Barat oleh Ikhlima Yaumil Putri Bansu tahun 2017 yang merupakan judul skripsi S1 beliau di Program Studi Pendidikan Agama Islam Fakultas Agama Islam Universitas Muhammadiyah Makassar; (4) Analisis keefektivan pembelajaran berbasis kurikulum 2013 di Sekolah Dasar oleh Kasmawanti, sudah di publish dalam Journal of Educational Science and Technology (EST) tahun 2017.

Tujuan kegiatan workshop kurikulum 2013 di Madrasah Ibtidaiyah Daarushofa Karang Tengah-Kota Tangerang ada 2 (dua) yaitu tujuan internal dan tujuan eksternal. Tujuan kegiatan yang terbagi dalam internal dan eksternal sebagai berikut:

\section{Tujuan Internal:}

a. Membiasakan diri peduli terhadap kebutuhan masyarakat dan dunia Pendidikan di lingkungan untuk membantu mereka untuk mencapai kehidupan yang lebih baik, Makmur dan sejahtera serta memahami tentang kebijakan Pendidikan yang sedang dilaksanakan.

b. Meningkatkan kompetensi dosen di bidang pedagogik, profesional, sosial, dan kepribadian; 
c. Memperkenalkan

Universitas

Pamulang agar masyarakat tertarik untuk berkuliah karena kampus Universitas Pamulang berkualitas dan murah biayanya.

\section{Tujuan Eksternal}

a. Agar pengetahuan yang kami berikan yaitu Workshop Kurikulum 2013 dapat menjadi pedoman bagi masyarakat terutama di Madrasah Ibtidaiyah Daarusshofa Karang Tengah untuk memaahmi dan menjalankan kurikulum 2013 dengan baik dan benar.

b. Untuk meningkatkan kepedulian sosial dosen Fakultas Keguruan dan Ilmu Pendidikan jurusan Pendidikan Pancasila dan Kewarganegaraan terhadap masyarakat, khususnya di Kecamatan Karang Tengah Kota Tangerang.

c. Untuk meningkatkan dan menjadi bahan acuan dalam pembentukan pendidikan yang lebih bermutu di wilayah setempat.

\section{Manfaat Pengabdian Masyarakat}

Adapun manfaat Pengabdian Kepada Masyarakat yang dilakukan di MI Daarusshofa adalah:

1. Membantu guru dan kepala Sekolah di Madrasah Ibtidaiyah Daarushofa Karang Tengah - Kota Tangerang lebih memahami dalam melaksanakan Kurikulum 2013.

2. Membantu kelengkapan administrasi Sekolah di Madrasah Ibtidaiyah Daarushofa Karang Tengah - Kota Tangerang berkaitan dengan pelaksanaan kurikulum 2013.

\section{Solusi yang dipilih}

Sesuai dengan tujuan Pengabdian Kepada Masyarakat di atas maka solusi yang dipilih yaitu mengefektifkan workshop kurikulum 2013 di sekolah Madrasah Ibtidaiyah Daarusshofa agar sekolah (kepala sekolah, guru, tenaga administrasi) dapat melaksanakan kurikulum 2013 lebih baik lagi. Adapun workshop yang dilakukan selama 3 (tiga) tersebut melakukan berbagai aktifivitas sebagai solusi untuk memberikan pemahaman pada peserta.

Workshop Kurikulum 2013 yang dilaksanakan di Madrasah Ibtidaiyah Daarushofa diawali dengan pengisian test awal yang sudah dipersiapkan oleh Tim 50 
PKM yang berupa pilihan ganda. Dalam butir-butir pertanyaan yang telah disiapkan berisi tentang: Beberapa aspek silabus tematik di Sekolah Dasar, Komponenkomponen Rencana Pelaksanaan Pembelajaran (RPP) pembelajaran tematik SD, tahapan pengembangan RPP pembelajaran tematik, pengertian pembelajaran tematik, tujuan pendekatan pembelajaran tematik, latar belakang pemilihan tema di SD, ciri pendekatan tematik, manfaat pembelajaran tematik terpadu, beberapa tahapan dalam pembelajaran tematik, model pembelajaran tematik, alasan pengecualian mata pelajaran agama tidak ditematikkan, tujuan penggunakan model pembelajaran jejaring, keuntungan dari penggunaan tema pada pembelajaran tematik, prinsip perumusan tema dalam tematik, evaluasi dalam tematik, penilaian yang tepat untuk pembelajaran tematik, prinsip penilaian dalam pembelajaran tematik, bentuk-bentuk penilaian kompetensi sikap, tujuan penilaian tematik, aspek-aspek dalam penyusunan silabus pembelajaran saintifik di SD, urutan aspek-aspek RPP yang benar dalam pembelajaran saintifik di SD, dan lainnya (total 58 butir pertanyaan)

Seluruh Peserta workshop yang berjumlah 13 (tiga belas) orang mengisi test awal tersebut untuk mengetahui pemahaman mereka tentang kurikulum 2013. Dari 58 butir pertanyaan yang diajukan, ada seorang peserta yang mencapai paling tinggi nilainyanya, yaitu Ibu Fidya Fatayatul Muna, S.Hum dengan nilai 33 betul.

Tes pemahaman pembelajaran tematik di SD yang terdiri dari 58 butir dalam bentuk pilihan ganda. Adapun kisikisinya sebagai berikut:

Kisi-kisi instrumen tes pemahaman pembelajaran tematik di SD

\begin{tabular}{|c|c|c|c|}
\hline Dimensi 1 & Indikator & $\begin{array}{l}\text { Jenis } \\
\text { soal }\end{array}$ & $\mathrm{Jl}$ \\
\hline \multirow[t]{4}{*}{$\begin{array}{l}\text { Pembelajaran } \\
\text { tematik di } \\
\text { SD }\end{array}$} & $\begin{array}{l}\text { 1.Menguraikan } \\
\text { silabus, RPP } \\
\text { sesuai dengan } \\
\text { pembelajaran } \\
\text { tematik di SD }\end{array}$ & PG & 5 \\
\hline & $\begin{array}{l}\text { 2.Menggunakan } \\
\text { Pendekatan } \\
\text { sesuai dengan } \\
\text { Materi } \\
\text { pembelajaran } \\
\text { tematik di SD }\end{array}$ & PG & 5 \\
\hline & $\begin{array}{l}\text { 3.Menggali } \\
\text { Metode } \\
\text { pembelajaran } \\
\text { sesuai dengan } \\
\text { pembelajaran } \\
\text { tematik di SD }\end{array}$ & $P G$ & 5 \\
\hline & $\begin{array}{l}\text { 4.Menelaah } \\
\text { Sistem } \\
\text { penilaian } \\
\text { sesuai dengan } \\
\text { pembelajaran } \\
\text { tematik di SD }\end{array}$ & PG & 5 \\
\hline \multicolumn{4}{|l|}{ Dimensi 2} \\
\hline $\begin{array}{l}\text { Pembelajaran } \\
\text { saintifik di }\end{array}$ & $\begin{array}{l}\text { 5. Menguraikan } \\
\text { silabus, RPP }\end{array}$ & PG & 5 \\
\hline
\end{tabular}




\begin{tabular}{|c|c|c|c|}
\hline \multirow[t]{4}{*}{ SD } & $\begin{array}{l}\text { sesuai dengan } \\
\text { pembelajaran } \\
\text { saintifik di SD }\end{array}$ & & \\
\hline & $\begin{array}{l}\text { 6.Menggunakan } \\
\text { Pendekatan } \\
\text { Materi yang } \\
\text { sesuai dengan } \\
\text { pembelajaran } \\
\text { saintifik di SD }\end{array}$ & PG & 5 \\
\hline & $\begin{array}{l}\text { 7.Menggali } \\
\text { Metode } \\
\text { pembelajaran } \\
\text { yang sesuai } \\
\text { dengan } \\
\text { pembelajaran } \\
\text { saintifik di SD }\end{array}$ & PG & 5 \\
\hline & $\begin{array}{l}\text { 8. Menelaah } \\
\text { Sistem } \\
\text { penilaian } \\
\text { sesuai sesuai } \\
\text { dengan } \\
\text { pembelajaran } \\
\text { tematik di SD }\end{array}$ & PG & 5 \\
\hline \multicolumn{4}{|l|}{ Dimensi 3} \\
\hline \multirow{3}{*}{$\begin{array}{l}\text { Penilaian } \\
\text { otentik } \\
\text { dalam } \\
\text { pembelajaran } \\
\text { di SD }\end{array}$} & $\begin{array}{l}\text { 9.Mengukur } \\
\text { aspek sikap }\end{array}$ & PG & 5 \\
\hline & $\begin{array}{l}\text { 10.Mengukur } \\
\text { aspek } \\
\text { Pengetahuan }\end{array}$ & PG & 5 \\
\hline & $\begin{array}{l}\text { 11.Mengukur } \\
\text { aspek } \\
\text { keteram- } \\
\text { pilan }\end{array}$ & PG & 5 \\
\hline
\end{tabular}

Adapun hasilnya sebagai berikut: (1) seorang guru memiliki $\mathbf{3 3}$ butir dijawab benar dari 58 butir yang ditanyakan. (2) seorang guru memiliki 25 butir dijawab benar dari 58 butir yang ditanyakan. (3) seorang guru memiliki 21 butir dijawab benar dari 58 butir yang ditanyakan. (4) seorang guru memiliki 20 butir dijawab benar dari 58 butir yang ditanyakan. (5) seorang guru memiliki 18 butir dijawab benar dari 58 butir yang ditanyakan. (6) seorang guru memiliki 15 butir dijawab benar dari 58 butir yang ditanyakan. (7) seorang guru memiliki 14 butir dijawab benar dari 58 butir yang ditanyakan. (8) seorang guru memiliki 14 butir dijawab benar dari 58 butir yang ditanyakan. (9) dua orang guru memiliki 11 butir dijawab benar dari 58 butir yang ditanyakan. (10) seorang guru memiliki 10 butir dijawab benar dari 58 butir yang ditanyakan. (11) dua orang guru memiliki 9 butir dijawab benar dari 58 butir yang ditanyakan. Dari hasil tes di atas terlihat bahwa pemahaman responden terhadap pembelajaran tematik di SD masih rendah. Setelah mengikuti workshop pemahaman mereka tentang pembelajaran tematik dan saintifik di SD semakin meningkat.

\section{METODE}

Pengabdian Kepada Masyarakat dilakukan di Madrasah Ibtidaiyah Daarushofa Karang Tengah-Kota Tangerang pada tanggal 5 - 7 Juli 2021.

Adapun target kegiatan adalah kepala sekolah, guru dan tenaga administrasi di sekolah tersebut. Metode yang digunakan dalam kegiatan workshop kurikulum 2013 yaitu:

a. Metode Ceramah bervariasi 
Metode ceramah dipilih untuk memberikan penjelasan tentang pentingnya Workshop kurikulum 2013 dan seperangkat dokumen yang harus disiapkan sekolah.

Adapun materi yang telah dipersiapkan oleh pemateri dalam memberikan ceranah bervariasi yaitu:

(1) Inovasi pembelajaran sesuai kurikulum 2013

(2) Penilaian hasil belajaran

(3) Penyusunan Program tahunan, dan Program semester

(4) Kriteria Ketuntasan Minimal (KKM)

Metode ceramah bervariasi dilakukan karena lebih effektif. Peserta dapat menanyakan langsung materi yang kurang dipahami. Variasi ceramah yang dilakukan juga dengan menanyakan video pembelajaran tematik di Sd sehingga peserta lebih mantap dalam melaksanakan kurikulum 2013.

b. Metode Tanya Jawab

Metode Tanya jawab sangat penting bagi para peserta Kegiatan. Metode tanya jawab dilakukan pada saat kegiatan ceramah atau pemaparan berlangsung. Selain itu, peserta juga melakukan diskusi yang berkaitan dengan materi kurikulum 2013.

c. Metode Simulasi

Metode simulasi ini diberikan kepada para peserta kegiatan dengan memberikan contoh dokumen kurikulum 2013 (kurikulum, silabus, RPP, penilaian) dan peserta mempraktekkan membuat silabus dan RPP serta praktek mengajar dengan menggunakan dokumen tersebut. Pada saat praktek mengajar dilakukan maka tim PKM menyiapkan format observasi yang merangkum kegiatan praktek sesuai dengan pembelajaran kurikulum 2013.

\section{Hasil Pembahasan}

Hasil selengkapnya kegiatan PKM berupa workshop kurikulum 2013 di Madrasah Ibtidaiyah Daarusshofa Karang Tengah- Kota Tangerang sebagai berikut:

1. Tanggal 5 Juli 2021, tim PKM sampai di tempat workshop pukul 08.00 pagi dan acara pembukaan dimulai dengan pembacaan kalam Ilahi Al Qur'an oleh seorang guru MI Daarushofa.

Acara dilanjutkan dengan Tes pemahaman tentang pembelajaran tematik SD selama 20 menit dan dilanjutkan dengan pemaparan inovasi 
pembelajaran kurikulum 2013 oleh Dr.

Lili Nurlaili, M.Ed. Dalam Paparannya beliau menjelaskan bahwa Peraturan Mentri Pendidikan dan Kebudayaan yang terakhir mengenai kurikulum 2013 yaitu:

- Permendikbud no. 20 th. 2016 ttg Standar Kompetensi Lulusan

- Permendikbud no. 21 th. 2016 ttg Standar Isi

- Permendikbud no. 22 th. 2016 ttg Standar Proses

- Permendikbud no. 23 th. 2016 ttg Standar Penilaian

- Permendikbud no. 24 th. 2016 ttg Kompetensi inti dan Kompetensi Dasar jenjang Pendidikan Dasar dan menengah

Materi berikutnya mengenai kemampuan abad 21 yang berimplikasi pada peserta didik yaitu:

(1)Kemampuan untuk melakukan pembaharuan yang terdiri dari: berpikir kritis dan penyelesaian masalah; kreativitas dan inovasi; komunikasi dan olaborasi

(2) Kemampuan literasi digital, misalnya: literasi informasi, literasi media dan literasi teknologi

(3) Kemampuan kecakapan hidup, antara lain: Fleksibilitas dan Adaptabilitas; Inisiatif dan Mandiri;
Interaksi Lintas Sosial-Budaya; Produktivitas dan Akuntabilitas; Kepemimpinan dan Tanggung Jawab.

Sedangkan prinsip pembelajaran yang digunakan dalam kurikulum 2013 sesuai dengan Permendikbud nomor 22 tahun 2016 tentang standar proses yaitu:

(1) Siswa mencari tahu;

(2) Belajar berbasis aneka sumber belajar;

(3) Penguatan pendekatan ilmiah;

(4) Pembelajaran berbasis kompetensi;

(5) Pembelajaran terpadu;

(6) Pembelajaran dengan jawaban multi dimensi;

(7) Keterampilan aplikatif;

(8) Menjadi seorang yang memiliki keinginan untuk belajar seumur hidup;

(9) Pembelajaran yang menerapkan di depan sebagai panutan, ditengah sebagai pendorong, dan dibelakang sebagai penyemangat;

(10)Pembelajaran yang berlangsung di lingkungan kehidupan seharihari

(11) Prinsip pembelajaran yang menekankan bahwa siapa saja adalah guru, siapa saja adalah 
peserta didik, dan di mana saja adalah kelas;

(12) Menggunakan teknologi yang tepat guna dan tepat sasaran untuk pembelajaran; dan

(13) Adanya ketidak samaan individual dan keluarga setiap peserta didik.

Kegiatan hari pertama di akhiri pada pukul $\quad 16.00$ sore dan peserta ditugaskan untuk membuat silabus dan RPP yang akan dipraktekkan ke esokan hari.

Pada hari kedua, diawali pukul 08.00 pagi dengan praktek mengajar berdasarkan rencana kegiatannya. Adapun hasil observasi praktek mengajar yang dilakukan oleh tim PKM Sdri. Lana Levia sebagai berikut: Nama guru yang diamati adalah Nita Novita yang mengajar kelas I SD dengan tema Diriku/Tubuhku. Sebelumnya Sdri. Lana levia memeriksa kelengkapan mengajar guru tersebut yaitu silabus dan RPPnya. Waktu mengajar selama $2 \times 35$ menit.

Guru mengawali kegiatan dengan meminta salah satu siswa ke depan memimpin do'a. yang menjadi siswa adalah guru peserta workshop karena sekolah sedang libur. Kegiatan dilanjutkan dengan pengecekan daftar hadir oleh guru. Kemudian menanyakan tentang bilangan 1-
10 pada siswa. Dilanjutkan dengan menyanyikan lagu yang sesuai tema. Guru kemudian melakukan tanya jawab pada siswa tentang akibat baca buku sambil tiduran. Siswa maju ke depan kelas dan bercerita tentang cara duduk yang baik dan benar.

Guru kemudian memberikan penjelasan untuk melakukan bilangan dengan menggunakan jari. Dilanjutkan kegiatan guru duduk yang sesuai dengan kesehatan, kemudian siswa mengikutinya. Guru kemudian menayangkan gambar anggota tubuh dan dilanjutkan dengan membuka buku paket tema 1 .

Siswa diminta guru untuk melakukan diskusi tentang cara duduk dan menghitung dengan menggunakan jari. Kemudian guru menanyakan bagaimana cara duduk yang benar.

Guru menekankan kembali cara duduk yang benar dan bilangan $1-10$. Apabila duduk tidak benar akan mengakibatkan tulang menjadi bungkuk demikian penjelasan guru.

Guru kemudian melakukan diskusi dengan peserta didik dan melakukan tanya jawab berkaitan dengan materi yang beliau sampaikan. 
Sebelum ditutup kegiatan hari itu, guru menanyakan kembali pada peserta didik mengenai pemahaman peserta didik terhadap materi yang beliau sampaikan hari ini.

Selama kegiatan pembelajaran berlangsung, peserta didik sangat antusias dan selalu menjawab pertanyaan guru dengan benar. Peserta didik juga aktif dalam kegiatan pembelajaran karena mereka banyak bertanya pada guru. Selain itu, mereka menjawab pertanyaan guru dengan sigap, lantang dan apa adanya sesuai yang mereka alami sehari-hari.

Kekuatan guru dalam mengajar adalah kelengkapan dokumen beliau yaitu Silabus dan Rencana Pelaksanaan Pembelajaran (RPP), selain itu guru menyiapkan media yang tersedia yaitu buku dan lagu-lagu yang sesuai tema. Guru juga mampu mengaitkan mata pelajaran matematika dan bahasa Indonesia dalam tema diriku tersebut.

Dari paparan $\mathrm{Bu}$ guru nita maka memperoleh nilai 87\%, artinya beliau menguasai inovasi pembelajaran yang sesuai dengan kurikulum 2013. Nilai $87 \%$ didapatkan dari penghitungan setiap aktivitas yang muncul diberi skor 1 dan setiap aktivitas yang tidak muncul sesuai format observasi yang telah disiapkan diberi skor 0 (nol). Rumus sbb

$$
\mathrm{P}=\mathrm{x} / \mathrm{n} \mathrm{X} 100 \% \text {. }
$$

2. Hasil Focus

Group Discussion (FGD).

Hari terakhir, kegiatan PKM dilanjutkan dengan melakukan kegiatan Focus Group Discussion (FGD) pada peserta yang dibagi dalam tiga kelompok. Diskusi terbagi dalam 3 topik besar yaitu topik pertama berkaitan tentang pembelajaran tematik di SD, topik kedua berkaitan tentang pembelajaran saintifik di SD dan topik ketiga berkaitan tentang penilaian otentik dalam pembelajaran di SD

Hasil kelompok pertama:

Kelompok pertama dengan 4 responden menghasilkan FGD sebagai berikut: Topik 1 yang terdiri dari 4 pembahasan (a) menurut peserta, silabus dan RPP Kurikulum 2013 lebih rumit dan sulit dibandingkan dengan kurikulum sebelumnya. Kesulitan yang mereka rasakan karena menyusunnya membutuhkan proses yang panjang. (b) Pendekatan digunakan antara lain: ceramah, diskusi dan tanya jawab. (c) Metode dan teknik pembelajaran yang mereka gunakan di sekolah adalah ceramah, hafalan, tanya jawab dan membuat 
siswa menjadi aktif. (d) Sistem penilaian yang guru-guru gunakan di sekolah adalah penilaian formatif dan sumatif. Topik 2 terdiri dari 4 pembahasan yaitu (a) Semua guru-guru/peserta kelompok pertama mengatakan bahwa silabus dan RPP yang yang mereka uraikan sudah sesuai dengan pembelajaran saintifik di Sekolah Dasar. (b) Pendekatan dan strategi pembelajaran yang mereka gunakan dalam materi pembelajaran saintifik di SD adalah discovery learning, problem solving dan problem based learning. (c) Penerapan berbagai metode dan teknik yang mereka lakukan sesuai dengan tahapan metode tersebut dan juga dengan menggunakan kuis, tanya jawab dan lainnya. (d) Sistem penilaian yang mereka terapkan di sekolah adalah tes tulis, praktek, hafalan, portofolio, dan ulangan. Topik 3 terdiri dari 5 pembahasan (a) menurut mereka penilaian otentik adalah penilaian murni dari nilai peserta didik. Penilaian tersebut adalah asli, nyata, valid atau reliabel. (b) Peserta mengatakan bahwa tujuan penilaian otentik adalah untuk mengetahui pemahaman dan kemampuan peserta didik sehingga mereka menjadi pembelajar yang berhasil menguasai pengetahun, melatih keterampilan peserta didik dalam menggunakan pengetahuannya dalam konteks kehidupan nyata sehari-hari mereka serta memberi kesempatan peserta didik mampu untuk menyelesaikan masalah yang mereka hadapi. (c) Guru-guru melakukan penilaian di kelas yaitu dengan observasi, jurnal dan formatif. (d) Penilaian otentik yang mereka lakukan memnuhi beberapa aspek yang diukur yaitu sikap, pengetahuan dan keterampilan. (e) Cara-cara melakukan aspek penilaian otentik yang mereka lakukan adalah dengan melihat sikap peserta didik, keaktifan dan kerjasama di dalam kelas.

Kelompok kedua dengan 3 responden menghasilkan FGD sebagai berikut: Topik 1 (a) Menurut mereka silabus dan RPP Kurikulum 2013 sudah cukup bagus karena membuat peserta didik lebih aktif. Dengan adanya silabus dan RPP kurikulum 2013 maka guru memiliki panduan untuk kegiatan yang membuat peserta didik aktif di kelas. (b) Pendekatan strategi yang mereka gunakan di sekolah adalah pendekatan saintifik dengan mengenalkan alam dan lingkungan sekitar. (c) Metode dan teknik pembelajaran yang mereka gunakan di sekolah adalah ceramah dan praktek menggunakan games dan eksplorasi. (d) Sistem penilaia yang mereka gunakan adalah tes tertulis, hafalan dan tes lisan. Di awali dengan pembuatan soal dan dilanjutkan dengan hafalan dan dinilai dengan tes tulis dan lisan. Topik 2 (a) menurut mereka, isi silabus dan RPP yang mereka uraikan belum keseluruhan membuat pembelajaran 
saintifik. (b) Pendekatan strategi pembelajaran yang mereka pergunakan dalam materi pembelajaran saintifik di SD yaitu tanya jawab, dengan menanyakan banyak hal mengenai materi pelajaran kepada peserta didik. (c) Cara mereka melakukan pembelajaran saintifik di SD yaitu dengan menggunakan alat peraga dan juga peserta didik di ajak ke lapangan/lingkungan sekolah. (d) Sistim penilaian yang mereka terapkan di sekolah yang sesuai dengan pembelajaran saintifik adalah membuat kisi-kisi soal yang tidak hanya berupa hafalan. Topik 3 (a) pengertian penilaian otentik menurut mereka adalah penilaian tulisan yang lebih membuat siswa mencari jawaban. (b) peserta tidak memahami tujuan diadakannya penilaian otentik. (c) penilaian yang dilakukan oleh peserta di dalam kelas yaitu penilaian sikap, lingkungan, keterampilan, pengetahuan dan tanya jawab. (d) Aspek yang mereka ukur pada saat melakukan penilaian otentik adalah aspek spritual dan pengetahuan. (e) Caracara yang mereka lakukan dalam melakukan penilaian otentik adalah dengan diskusi dan menyimpulkan bersama peserta didik, baik dalam kelompok maupun individu.

Kelompok ketiga dengan 4 responden menghasilkan FGD sebagai berikut. Topik 1 (a) Menurut responden, silabus dan RPP dalam kurikulum 2013 terdapat perbedaan dengan Kurikulum tingkat satuan pendidikan (KTSP) atau kurikulum 2006. (b) Metode dan Teknik pembelajaran yang mereka gunakan di sekolah adalah ceramah dan eksperimen. (c) Sistim penilaian yang mereka gunakan adalah bentuk soal, tanya jawab dan tes tertulis. Topik 2 (a) menurut mereka, isi silabus dan RPP yang mereka uraikan baru sebagian saja yang sesuai dengan pembelajaran saintifik di SD. (b) Pendekatan saintifik di SD dengan problem solving. (c) Penerapan pembelajaran saintifik di SD yang mereka lakukan yaitu dengan games dan lainnya. (d) sistim penilaian yang mereka berikan sesuai dengan pembelajaran saintifik di SD yaitu dengan diskusi dan tanya jawab. Topik 3 (a) mereka mengatakan bahwa penilain otentik yang mereka ketahui adalah penilaian keterampilan. (b) menurut mereka, tujuan diadakannya penilaian otentik adalah agar orang tua mengetahui capaian pembelajaran peserta didik secara langsung. (c) penilaian yang mereka lakukan di kelas adalah memberikan soal dan tanya jawab. (d) menurut mereka, penilaian otentik hanya pengukur aspek pengetahuan saja. (e) Caracara melakukan penilaian otentik menurut mereka adalah dengan diskusi.

\section{Hasil kepuasan peserta terhadap} pelaksanaan workshop. 
Pada akhir pelaksanaan workshop, peserta diminta mengisi angket mengenai kepuasan mereka terhadap pelaksanaan workshop. Adapun hasilnya sebagai berikut: (1) Sebanyak 6 orang peserta mengatakan bahwa pemateri menyampaikan materi dengan jelas dan terstruktur; (2) Ada 5 orang peserta yang mengatakan pemateri menguasi materi yang disampaikan dan masalah terkait lainnya; (3) Ada 6 orang peserta yang mengatakan pemateri menambah wawasan mereka selama kegiatan berlangsung; (4) Ada 5 orang peserta yang menyatakan

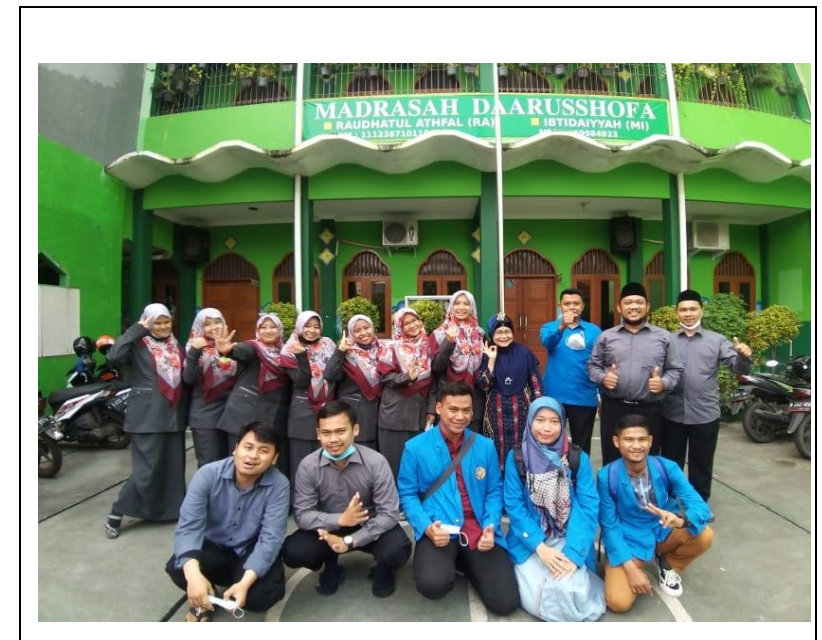

Foto Bersama Guru, Kepala sekolah dan narasumber workshop Kur. 2013 di Madrasah Ibtidaiyah Daarusshofa tgl 5-7 Juli 2021

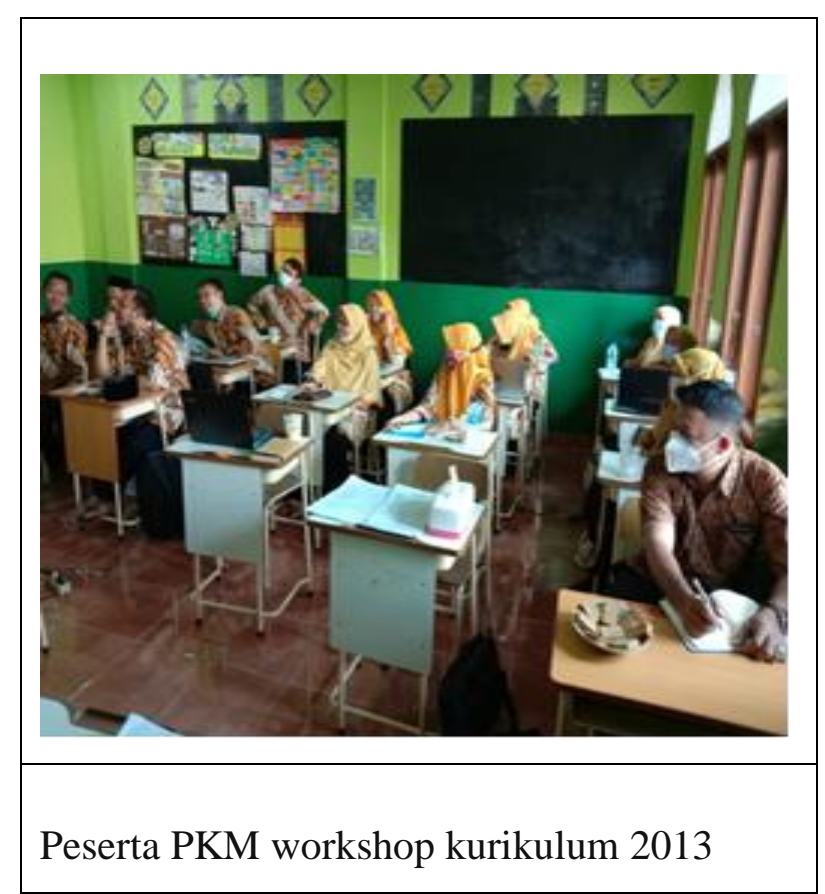
pemateri menjawab pertanyaan dengan effektif dan memuaskan; (5) Ada 5 orang berpendapat bahwa pemateri sangat menguasai yang disampaikan; (6) Ada 4 orang mengatakan bahwa paparan singkat dan informatif; (7) ada 6 orang peserta menyatakan bahwa materi paparan berisi contoh-contoh yang terkait dengan pekerjaan mereka saat ini; (8) ada 7 orang peserta menyatakan bahwa alat bantu visual dan power point sangat membantu mereka dalam memahami materi; (9) ada 6 orang berpendapat secara keseluruhan materi paparan bermanfaat; (10) ada 4 orang berpendapat materi paparan terorganisir dan menarik. 


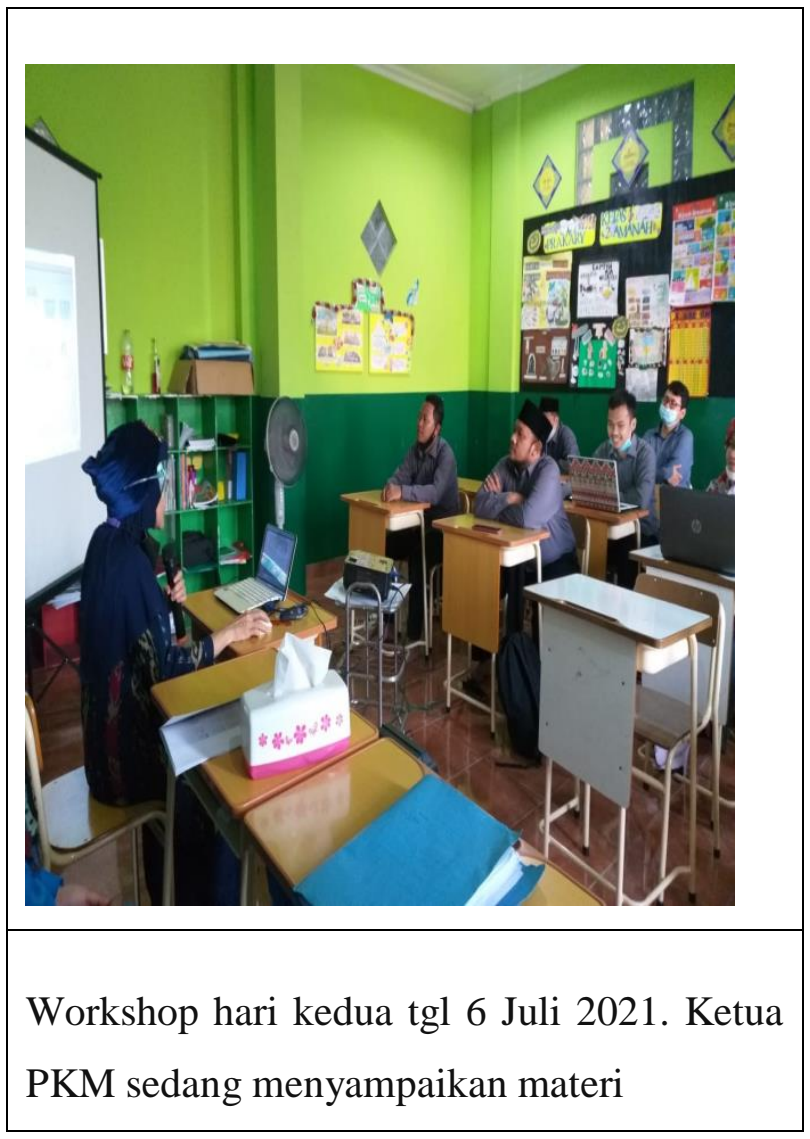

Kesimpulan

Kesimpulan: Dari hasil penelitian yang dilaksanakan di Madrasah Ibtidaiyah Daarushofa mengenai effektifitas inovasi pembelajaran kurikulum 2013 melalui kegiatan workshop dapat disimpulkan bahwa sekolah tersebut telah mampu melakukan inovasi pembelajaran kurikukulum 2013, baik secara teori maupun praktek. Hal itu dibuktikan dengan hasil observasi yang dilakukan pada saat guru melakukan praktek mengajar. Maupun hasil focus group discussion (FGD) dan tes pemahaman pembelajaran tematik di SD. Beberapa prinsip inovasi pembelajaran kurikulum
2013 telah dilaksanakan oleh guru yaitu (1) peserta didik sebelumnya hanya diberi tahu, menjadi peserta didik yang mencari tahu; (2) peserta didik belajar dari berbagai macam sumber belajar terutama sumbelajar dari lingkungan sekitar kehidupan mereka, jadi tidak hanya bersumber dari buku paket saja.; (3) Peserta didik mampu belajar dengan menggunakan berbagai sumber belajar, baik sumber belajar tercetak, video, games, maupun yang ada di lingkungan sekitar; (4) Peserta didik sudah mampu belajar dengan melalui pendekatan tematik terpadu yaitu melalui tema dipadukan beberapa mata pelajaran dalam satu pertemuan; (5) Peserta didik juga mampu belajar dengan menggunakan pembelajaran berbasis kompetensi sesuai dengan Kurikulum 2013.

Dari hasil FGD juga membuktikan bahwa setelah mengikuti workshop maka peserta lebih percaya diri dalam melakukan menyusun silabus, RPP dan penilaian sesuai dengan kurikulum 2013.

Dari hasil tes pemahaman responden terhadap pembelajaran tematik di SD dan pembelajaran saintifik di SD juga menunjukkan bahwa mereka menjadi paham setelah mengikuti workshop tersebut.

Saran: Perlu dilakukan terus menerus pendampingan terhadap sekolah-sekolah 
yang melaksanakan kurikulum 2013 dan merasa mereka masih banyak kendala, terutama kendala dalam melakukan inovasi pembelajaran sesuai kurikulum 2013.

\section{REFERENSI}

Undang-undang Sistem Pendidikan Nasional, nomor 20 tahun 2003 https://peraturan.bpk.go.id/Home/Details/4392 0/uu-no-20-tahun-2003

Bansu, Ikhlima Yaumil Putri (2017), Efektivitas Penerapan Kurikulum 2013 dalam Meningkatkan Mutu Pembelajaran PAI dan Budi Pekerti di SMPN 2 Wonomulyo Provinsi Sulawesi Barat. https://digilibadmin.unismuh.ac.id/

Kasmawanti (2017), Analisis keefektivan pembelajaran berbasis kurikulum 2013 di Sekolah Dasar. https://ojs.unm.ac.id/JEST/index

Mudiono, Alif, dkk. Workshop pembelajaran tematik terpadu berbasis inovatif dan kreatif bagi guru-guru di kota Belitar yang dilaksanakan oleh mahasiswa Fakultas Ilmu Pendidikan Universitas Negri Malang pada tahun. 2017. http://lib.um.ac.id

Dibid, I ketut, dkk. Seminar dan workshop pembelajaran berbasis kurikulum 2013 bagi guru-guru SD di Kecamatan Busungbiu, Kabupaten Buleleng-Propinsi Bali pada tahun 2017 yang dilaksanakan oleh mahasiswa FIP Undiksa. http://ejournal.undiksa.ac.id
Workshop Kurikulum 2013, Jurusan Pendidikan Guru Madrasah Ibtidaiyah IAIN Surabaya pada tahun 2018. $\underline{\text { https://pddikti.kemdikbud.go.id }}$

Alfiana, Cici (2019). Efektivitas Kurikulum 2013 dalam Proses Pembelajaran Pendidikan Agama Islam dan Budi Pekerti di kelas XI SMA Negeri Bona. http://repository.umsurabaya.ac.id/4456/2

Dewi, Ika Nurani, dkk. Workshop penilaian kurikulum 2013 yang dilaksanakan oleh FKIP UNRAM tahun 2019 di Yayasan Al Azhar NW. Kayangan pada tahun 2019. https://core.ac.uk

Gumanti, Redmon Windu (2020). Inovasi Pendidikan Dalam Efektifitas Penerapan Kurikulum 2013. http://jurnal.syntaximperatif.co.id/index.p hp/syntax-imperatif/article/view/47 
Jurnal Loyalitas Sosial

Vol.3 No. 2 September 2021
Journal of Community Services in Humanities and Social Sciences p-ISSN 2655-9072 | e-ISSN 2686-1380 